\title{
Integrating the Value Pro Environmental Behavior (PEB) and Knowledge of Ecosystem Concept to Improve Students' Critical Thinking Skill: Environmental Learning Based Project
}

\author{
Evita Anggereini ${ }^{1, *}{ }^{*}$ odion Siburian ${ }^{2}$
}

\author{
12 Universitas Jambi \\ *Corresponding author. Email: evita_pklh@yahoo.com
}

\begin{abstract}
The critical thinking skill is needed to analyze environmental problems that occur. Along with the increasing environmental damage due to human behavior and activities, a solution is needed that must be sought immediately. Through the learning environment, these skills are used to analyze problems, look for causes and effects of problems, find out how these problems occur and find a solution plan. Learning mini research projects that are integrated with the value of Pro Environmental Behavior (PEB) facilitates the development of this ability by exposing students to "real life" problems which are then carried out a critical study, determining the solution to these problems and followed up with the project. This study aims to see the effect of the learning environment based on a mini research project integrating PEB and ecosystem knowledge to students' critical thinking skills. This research is an experimental study with a $2 \times 2$ factorial design. The research variable is a learning model in the form of a mini research project learning model integrated PEB and conventional models, and the attribute variable is ecosystem knowledge which consists of 2 factors: high and low ecosystem knowledge. The instruments used were questionnaires, tests, observation sheets and documentation. The research sample consisted of 97 students. This research was conducted for 6 months. The data analysis technique used descriptive data analysis and 2-way ANOVA inferential statistics. The results showed that there was an effect of this learning model on critical thinking skills; meanwhile, ecosystem knowledge has no effect on critical thinking skills. There is no interaction between the learning model and the level of ecosystem knowledge on critical thinking skills. Thus, these learning models can be implemented in a learning environment.
\end{abstract}

Keywords: Mini Research Project Learning, Pro Environmental Behaviour, Critical Thinking Skill.

\section{INTRODUCTION}

Environmental damage is mostly caused by improper human behaviour in interacting with the environment. This environmental damage threatens the survival of living things, including humans. Environmental education is provided through formal education either with an integrated or monolithic approach aimed at developing problem-solving skills for students or students through critical analysis of the environmental problems it finds. These skills are in the form of critical thinking skills, knowledge, attitudes.

Environmental education aims to make students develop problem-solving skills, make decisions and participate actively in the environment. It is expected that from a critical analysis of environmental problems and the damage they cause, it can provide students with provisions to overcome environmental problems they find and determine how they behave and behave. True to the environment. The behaviour that saves the environment is in the form of pro environmental behaviour (Pro Environmental Behaviour).

Pro-environmental behaviour is needed to maintain a sustainable environment, with regard to energy-saving behaviour, water, soil, reducing waste, pollution [1], establishing a relationship with nature [2], regarding cognitive flexibility, [3]. Critical thinking skills can be developed through learning model management. [4]. Critical thinking skills can be improved through mini project learning activities in the laboratory [5]. 
Environmental learning requires a critical study of every environmental problem that occurs in finding alternative solutions to these environmental problems. Critical thinking skills can be developed through learning model management [4]. Critical thinking skills can be improved through mini project learning activities in the laboratory [5].

Based on the results of observations of environmental learning for both medium and high levels, students are less exposed to environmental problems directly and are less involved in observing the damage they cause directly (real life) so that they do not touch the awareness to behave correctly in the environment. Therefore, it is necessary to develop an environmental learning model that can develop critical thinking skills in learning environments. The learning model is a mini research project based on a learning environment. Mini research project learning is a learning process that exposes students to "real life" problems which are then carried out for critical studies, determining solutions to these problems and followed up with the project. This learning can help deepen problems and provide meaningful experiences through critical studies and the solutions offered [6]. The basic knowledge that students must have is knowledge of the concept of ecosystems. This knowledge is used in conducting critical analysis studies and determining solutions to environmental problems found.

The improvement in behaviour towards the environment is influenced by a person's ability to critically analyse environmental problems around him. This ability is known as critical thinking ability [7]. Critical thinking skills must be developed in learning in accordance with the 21st-century learning framework [7]. The ability to think critically about environmental problems is expected to be an asset to find the right solution for each environmental problem. On the other hand, there are also other factors that influence the development of these two skills, namely the knowledge factor about the concept of ecosystems that students have. By collaborating these two factors in helping improve students' critical thinking skills, students will sharpen their critical analysis and problem skills. the solutions offered for each of these environmental problems. This of course leads to the end result, of course, having an impact on changing students' environmental behaviour in interacting with their environment appropriately and naturally. This is an effort to create a sustainable environment for present and future generations.

The decline in environmental quality is generally the result of human untruth in behaving towards the environment. Degradation of environmental quality is mostly caused by human behaviour towards the environment. The decreasing quality of the environment will certainly threaten the sustainability of future generations. This decline in the value and function of the environment certainly does not only directly threaten human life, but more broadly threatens all species living on earth. Environmental damage occurs due to incorrect human behaviour in interacting with the environment. Damage is caused by behaviour, so the repair must also be behavioural. The behaviour in question is proenvironmental behaviour. This behaviour includes behaviour that is caring, responsible, caring for and preserving the environment. Pro-environmental behaviour is needed to maintain a sustainable environment.

Behaviour to protect the environment in order to ensure the continuity of life today and in the future, is called pro-environmental behaviour [8]. Proenvironmental behaviour (PEB), 1. This behaviour includes the efficient use of water, energy and other resources. 2. Minimizing waste, pollution, and environmental gradation.[1]. Recycle and reuse, minimizing consumption of energy, then water and natural resources. [9].

Formal education seeks to ease changes in environmental behaviour through environmental learning for students by introducing an environmental-based education curriculum through an integrated approach to each subject or monolithically. Environmental learning which is carried out with an integrated and monolithic approach is still centred on the teacher (teacher centre). In higher education, this is manifested in the form of environmental science courses.

Changes in student environmental behaviour into Pro environmental Behaviour are influenced by the ability of students to observe, analyse, critically evaluate every fact, phenomenon, environmental problems that exist around students and are found in students' daily life (contextual). Contextual factors directly influence pro environmental behaviour [10]. Critical thinking factors affect pro environmental behaviour quality of thinking [11]. The results of this critical analysis are needed to find appropriate solutions students interact with their environment (problem solving skill).

Environmental learning which is integrated with the values of Pro Environmental Behaviour through a mini research project learning model is expected to develop students' critical thinking skills. These skills are needed to critically analyse environmental problems in order to find solutions to these problems. It is hoped that from a critical analysis study of environmental problems and the damage they cause, it can provide students with provisions to overcome the environmental problems they find and determine how they should behave and behave correctly in the environment. Critical thinking skills about environmental problems can be the basis for the design of developing lesson plans related to Environmental Knowledge subjects [12]. 
Research-based learning is a learning model that uses authentic learning, problem-solving, cooperative learning, contextual learning, and inquiry approaches that are guided by the philosophy of constructivism. Research-based learning can contribute to the growth of student skills in conducting research [13]. We found that problem-based mini project learning was used successfully in the learning experience in the laboratory because it stimulated students with "real life" problems. This is in line with Iryance's opinion [14], which states that project-based learning (mini research) can help develop understanding and appreciation of an event, provide an interesting learning experience and become more meaningful by developing critical thinking skills in understanding the realities of life and can solve every problem in real life.

The objectives of this study are (1) To determine the effect of a mini research project based environmental learning model that is integrated with the values of Pro Environmental Behaviour on students' critical thinking skills,(2) Knowing the effect of ecosystem knowledge on students critical thinking skills, (3) Knowing the interaction between having a mini research project that integrates the values of Pro Environmental Behaviour (PEB) and ecosystem knowledge on students' critical thinking skills.

\section{METHODS}

This research is an experimental study with a $2 \times 2$ random factorial design. The first independent variable is the learning model which consists of 2 factors, namely the environmental learning model based on a mini research project and a conventional model. The second independent variable as an attribute variable is knowledge about the concept of ecosystem. This knowledge consists of 2 factors, namely high ecosystem knowledge and low ecosystem knowledge (Table 1).

Table 1. 2x2 Factorial Random Design

\begin{tabular}{|c|c|c|}
\hline \multirow{2}{*}{$\begin{array}{l}\text { Knowledge of } \\
\text { Ecosystem } \\
\text { Concept (B) }\end{array}$} & \multicolumn{2}{|c|}{ Environmental Learning Models (A) } \\
\hline & $\begin{array}{l}\text { Mini Research } \\
\text { Project (A1) }\end{array}$ & $\begin{array}{l}\text { Conventional } \\
\text { (A2) }\end{array}$ \\
\hline High (B1) & A1B1 & A2B1 \\
\hline Low (B2) & A1B2 & A2B2 \\
\hline
\end{tabular}

The dependent variable is the student's Critical Thinking Skill. The population of this study were all students of the Biology Study Program who took Environmental Science courses in the even semester of 2019/2020. A total of 101 students were distributed in 3 classes: A, B and C. The sample was taken through purposive random sampling technique because this study used a sample that had strata in the knowledge of ecosystem concepts, namely: high and low obtained through pre-test about the concept of ecosystem. Students who have knowledge of the concept of ecosystems in moderate strata are not involved as samples. This is done to be able to see the effect of the attribute variables of the ecosystem concept knowledge on the dependent variable, namely critical thinking skills.

The instrument used was a test to obtain data on the ecosystem knowledge that students had. Data about students' critical thinking skills used test instruments, questionnaires and documentation. To obtain data, the research instrument used in this study was determined by the type of data to be collected. These instruments are

1. The observation sheet is used to observe and record all events that appear during the learning process. The observation sheet used uses a rubric to make it easier to describe and categorize the data to be obtained. Observation sheets to collect data about the feasibility of learning models, student activities.

\section{Critical Thinking Test Questions}

Critical thinking test questions are used to determine the level of critical thinking skills of students. This question is given after the action is given to students.

\section{Questionnaire}

The questionnaire was used to obtain data on students' critical thinking skills and student problem solving skills.

\section{Documentation}

Documentation is useful for completing data in addition to critical thinking and the implementation of learning strategies in the form of photos, videos and small notes. This data is needed to sharpen the study in the reflection stage to improve the weaknesses that exist in the cycle.

There are 2 types of data analysis techniques used in this study: descriptive data analysis techniques and inferential data analysis techniques which include hypothesis prerequisites in the form of normality tests and homogeneity tests followed by hypothesis testing with 2-way ANAVA test. The level of significance used is 0.05 .

\section{RESULTS AND DISCUSSION}

Table 2. Descriptive Analysis of Critical Thinking Skill on Mini Research Project Learning

\begin{tabular}{|l|l|l|}
\hline \multicolumn{1}{|c|}{ Source } & $\begin{array}{c}\text { Mini Research } \\
\text { Project Integrated } \\
\text { PEB }\end{array}$ & Conventional \\
\hline Mean & 14.65 & 11.60 \\
\hline Lower Bound & 13.51 & 10.88 \\
\hline Upper bound & 15.78 & 12.31 \\
\hline Minimum Score & 8.00 & 9.00 \\
\hline Maximum Score & 18.00 & 14.00 \\
\hline
\end{tabular}

The table above shows that the average score of Critical Thinking Skill in classes that receive mini research-based learning is higher than in classes that carry out conventional learning. In mini research learning, students make direct observations of 
environmental damage that occurs in the surrounding environment. They recorded their findings, documented and interviewed the surrounding community about how the damage occurred and the impact on society and the environment. Furthermore, students analyse their findings and think of appropriate solutions to overcome environmental damage. This step is carried out by each group with different observations, problems and solutions. Each learning group discusses in its own group the findings and planned solutions. This step is part of the centrality in the Mini Research Project learning stage.

Focus is meant here is that students in their learning group focus on findings of environmental damage found in the field. This is the realism stage in the mini research project learning-step. Then plan the solution by discussing it with the group members. Questions are raised, critical analysis, the accuracy of the project plans they make as a solution by seeing the weaknesses and strengths of the project they will make before the project is realized. This step is a step of Driving Question and Constructive Investigation. Steps like this will help students get clear evidence that can be seen before them in connection with the problems found. [15]. Thinking critically, they can analyze the problems they find critically, logically and correctly [16] and determine the right solution based on the problems they see [17]. Milton [18] stated that critical thinking is a cognitive skill starting from analysis, synthesis and evaluation which is used to see the problems that students find, understand the problem clearly because if it is not clear, it will risk the problem incorrectly [19].

Unlike the case with the control class which received conventional learning. Conventional what is meant here is that learning is carried out as usual. Environmental learning is carried out without any specific treatment intervention. They observe problems from the environment from the results of indirect observations in the field, but they get it from books, the internet and other learning sources. They are not directly dealing with environmental problems in the field. They still analyze the damage through discussion, but they do not think of a solution to be realized as a project. Emotional involvement, curiosity is certainly not as big as those who do mini research project learning. Thus, this will affect students' critical thinking skills. Moon [20], stated that other factors that influence critical thinking are emotion, language and curiosity.

The high critical thinking skills in students who receive mini research project learning is because students do more critical analytical studies when seeing the environmental damage directly based on the data findings they obtain. They carry out analytical studies from various aspects ranging from the results of the causes, the impact on society and the environment as well as critical analysis of the project in terms of the weaknesses and strengths of the project.
The Table 3 above shows that the learning environment model used affects students' critical thinking skills. This is indicated by the value sig. 0.000 $<0.05$. This can be explained that the involvement of students in seeing environmental problems clearly (clarity) will be more in students who receive miniresearch project learning compared to students who receive conventional learning. Likewise, the conclusions they make will certainly be sharper because they carry out analytical studies critical after the problem is clear. This sharper conclusion has an impact on the decisions taken to solve these problems. The involvement of every aspect in critical thinking is more numerous and deep in the experimental class.

The knowledge variable does not affect students' critical thinking skills. The non-impact of the knowledge variable, in this case ecosystem knowledge, can be caused by the concept of ecosystem knowledge that is not properly used in this learning model to improve students' critical thinking skills. In fact, environmental damage is marked by disturbances in the ecosystem so that the interaction between components in the ecosystem, both biotic and abiotic components, is also disturbed. Therefore, it is necessary to have the knowledge of ecosystems that students have as a basis for knowledge to critically analyze the environmental problems they find and then find solutions to these problems. These findings need to be followed up through further research by using other knowledge such as ecological knowledge, and, more specifically, knowledge about environmental pollution.

Table 3. Data Analysis Results Using Two Way Analysis Anova

\begin{tabular}{|l|c|c|c|c|c|}
\hline \multicolumn{1}{|c|}{ Source } & $\begin{array}{c}\text { Type III } \\
\text { Sum of } \\
\text { Squares }\end{array}$ & df & $\begin{array}{c}\text { Mean } \\
\text { Square }\end{array}$ & F & Sig. \\
\hline $\begin{array}{l}\text { Corrected } \\
\text { Models }\end{array}$ & $109.50^{\mathrm{a}}$ & 3 & 36.50 & 7.65 & .00 \\
\hline Intercept & 7352.98 & 1 & 7352.98 & 1540.30 & .00 \\
\hline Models & 98.05 & 1 & 98.05 & 20.54 & .00 \\
\hline Knowledge & .20 & 1 & .20 & .04 & .84 \\
\hline $\begin{array}{l}\text { Model * } \\
\text { Knowledge }\end{array}$ & 9.40 & 1 & 9.40 & 1.97 & .17 \\
\hline Error & 186.18 & 39 & 4.77 & & \\
\hline Total & 7825.00 & 43 & & & \\
\hline $\begin{array}{l}\text { Corrected } \\
\text { Total }\end{array}$ & 295.67 & 42 & & & \\
\hline
\end{tabular}

a. $\quad$ R Squared $=.370$ (Adjusted R Squared $=.322$ ) 


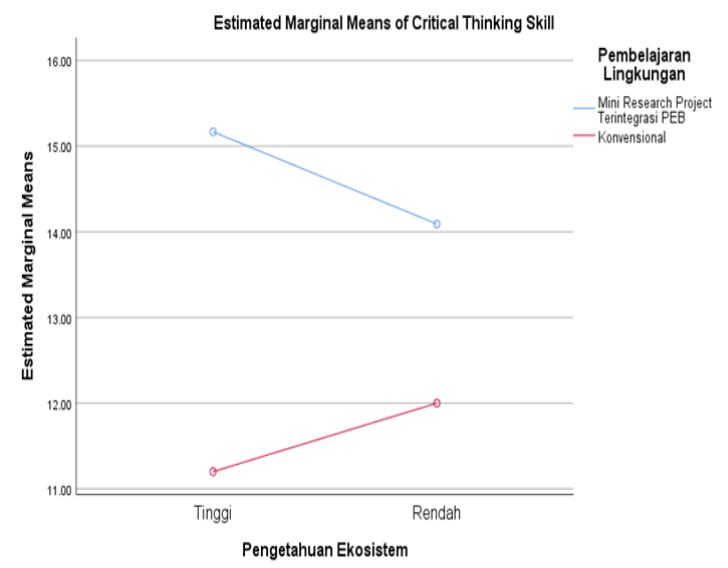

Figure 1. Graph of the interaction between learning models and ecosystem knowledge with Citical Thinking Skill.Caption content

The picture above shows that there is no interaction between environmental learning models and ecosystem knowledge on critical thinking skills.

\section{CONCLUSIONS}

The conclusions of this study are

1. Environmental-based learning Mini Research Project integrated with Pro Environmental Behavior influences students' critical thinking skill.

2. The critical thinking skills of students who receive a learning environment with PEB integrated Mini Research Project are higher than conventional learning.

3. Ecosystem knowledge has no effect on students' Critical Thinking Skills.

4. There is no interaction between environmental learning models and ecosystem knowledge on students' critical thinking skills.

\section{ACKNOWLEDGMENTS}

Thank you to FKIP and LPPM Jambi University which have assisted in conducting research and writing manuscripts.

\section{REFERENCES}

[1] N, Baker (2020) Sustainable Environmental Design in Architecture. New York: Springer, 2012.

[2] F Maria, C Silvia and I Fernanda, (2020) The Role of Urban/Rural Environments on Mexican Childrens Connection to Nature and Pro Environmental Behavior, Frontiers . Psychology.

[3] F Lange and S Dewitte, (2019) Cognitive Flexibility and Pro environmental Behaviour: A Multimethod
Approach) European Journal of Personality), volume 33. Issue 4 Wiley Online Library.

[4] K Changwong, A Sukkamart, B Sican B. (2018) Critical thinking skill development: Analysis of a new learning management model for Thai high schools, Journal of International Studies.,11(2),3748.

[5] A Hakim, Liliasari, (2016) Improvement of Student Critical Thinking Skills with the Natural Prroduct Mini Project Laboratory Learning, Indones.J.Chem.16(3).322-328.

[6] S M Leksono, \& Ekanara, (2019) Bambang. Profil Kemampuan Berpikir Kritis Siswa SMA Melalui Pembelajaran Mini-Riset Berbasis Pendidikan Konservasi. Prosiding Seminar Nasional Pendidikan FKIP.2(1): 218-223.

[7] S Lamb, Maire, Quentin., Doecke, Ester, (2017). Key Skills for 21st Century: an evidence based review.

[8] L Steg, (2007) Environmental Psychology an Introduction, Chichester:John Willey \&Sons.

[9] Arzah, (2002), B. Handbook of Environmental Psychology. New York: John Wiley \& Sons Inc.

[10] A Nordlund, Garvill. (2002) Value Structures Behind Proenvironmental Behavior. Sage Journals.: Environment and Behavior. 10. 1777.

[11] J Cincera, J Krajhanzl, (2013), Eco Schools: what factors influence pupis action competence for environmental behavior. Journal of Cleaner Production.Volume 61, 2013, pp. 117-121.

[12] N Santi, (2018). Kemampuan Berpikir Kritis Mahasiswa Pendidikan Biologi melalui Penyelesaian Masalah Lingkungan. BIOEDUKASI: Jurnal Pendidikan Biologi..11(1): 33-39.

[13] N Rangkuti, (2016). Pembelajaran Berbasis Riset Di Perguruan Tinggi. Batu Sangkar Internasional Conference,pp.141-152.[9].

[14] I Iryance, (2014), Pengaruh Metode Pembelajaran dan Berpikir Kritis terhadap Hasil Belajar Sejarah Siswa SMA Kesatuan Bogor. Jurnal Pendidikan Sejarah, 3(1): 13-22.

[15] P Eggen, P Kauchak, (2012) Strategi dan Model Pembelajaran: Mengajarkan Konten dan Keterampilan Berpikir. Terjemahan S. Wahono, Indeks, Jakarta,

[16] Z Hamid, \& H Zulkifli. (2014). Membina Kemahiran Berpikir Kritis dan Holistik di kalangan PelajarMenggunakan Modul Edwar De Bono. 
Journal of Social Science and Humanities. 9(2):001-013.

[17] M Sholihah \& S Susilo, (2016) Pengaruh Model Experiential Learning Terhadap Kemampuan Berpikir Kritis Siswa SMA, Jurnal Pendidikan, Teori Penelitian Pengembangan. 11:2096-2100.

[18] K Milton, (2008) Skills For OU Study Thinking Critically. United Kingdom: Thanet Press,.

[19] M Kallet, (2014) Thinking Smarter, Critical Thinking to Improve Problem Solving and Decsion Making Skills, John Wiley \& Sons. Inc, New Jersey.

[20] J Moon. (2008) Critical Thinking An Exploration of Theory and Practice. New York: Routledge, 2008. 